\title{
Induction of Defense Related Enzymes by $\beta$-aminobutyric Acid against Ralstonia solanacearum in Resistant and Susceptible Cultivars of Tomato
}

\author{
Garima Chaudhary ${ }^{1,2}$, Dinesh Singh ${ }^{1 *}$ and Manju Sharma ${ }^{2}$
}

${ }^{1}$ Division of Plant Pathology, Indian Agricultural Research Institute, New Delhi, India

${ }^{2}$ Amity Institute of Biotechnology, Amity University, Manesar, Haryana, India

*Corresponding author

\section{A B S T R A C T}

\section{Keywords}

\section{Ralstonia}

solanacaerum, Beta-butyric acid, Defense-Related Enzymes, Geneexpression

\section{Article Info}

Accepted:

12 January 2021

Available Online: 10 February 2021
Ralstonia solanacearum, one of the most important bacterial pathogen of tomato, is a constant threat to this crop. Plant-pathogen interactions are mediated by a complex network of molecular and cytological events that determine a range between susceptibility. Pusa ruby (susceptible) and Hawaii7996 (resistant) cultivar of tomato was treated with betabutyric acid

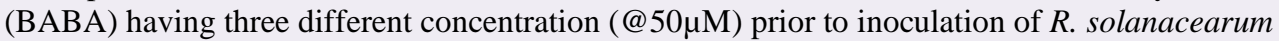
at intervals of 6,24, 48 and 96hpi using root drenching inoculation technique under control conditions. The role of defense-related enzymes in imparting resistance in tomato with chemical elicitor against $R$. solanacearum was investigated by quantifying enzymes activity and gene expression of three defense-related enzymes peroxidase (POD), catalase and superoxide dismutase (SOD). POD enzyme activity was noticed increased after inoculation with BABA $(50 \mu \mathrm{m})+R$. solanacearum upto $48 \mathrm{hpi}(3.76 \mathrm{~min} / \mathrm{mg}$ protein) in Pusa Ruby and (5.36 $\mathrm{min} / \mathrm{mg}$ protein) in Hawaii7996 whereas, kept decreased level at 96hpi as compared to control. The significant increase level of CAT activity was noticed in combination of BABA $(50 \mu \mathrm{M})+R$. solanacearum in both Pusa Ruby (25.58 $\mathrm{min} / \mathrm{mg}$ protein) and Hawaii7996 (31.58 $\mathrm{min} / \mathrm{mg}$ protein) cultivars at $48 \mathrm{hpi}$ and decreased level of SOD enzyme was noticed at $96 \mathrm{hpi}$ (17.91 $\mathrm{min} / \mathrm{mg}$ protein) Pusa Ruby and (29.91 $\mathrm{min} / \mathrm{mg}$ protein) Hawaii7996 as compared to control. The relative expression was recorded significant $(\mathrm{P}<0.005)$ high 2.61 fold upregulation after treated with pathogen in both cultivars as compared to control. Pusa Ruby cv. showed the significant highest values of gene expression with BABA $+R$. solanacearum treatment in both POD and SOD genes at 96hpi as compared to resistant cultivar of tomato. The relative expression CAT gene was found highest in resistant cv. Hawaii7996 and was lowest in the susceptible cv. Pusa Ruby. Minimum wilt incidence $5.54 \%$ was recorded in BABA $(50 \mu \mathrm{m})$ in resistant cv. Hawaii7996 followed by $9.14 \%$ in Hawaii7996 without BABA treatment and susceptible cv Pusa Ruby (29.10\%) after 28 days of inoculation of $R$. solanacearum. BABA also provided good health of plants of both the cultivars of tomato under glasshouse conditions.

\section{Introduction}

Tomato (Solanum lycopersicum L) is a protective food and has the second position after potato in vegetable crops in the world. The tomatoes is produced more than 126 million MT of and grown 4.6 million hectares annually in the World. In India, tomato has 
ranked $3^{\text {rd }}$ after potato and onion in priority and ranked second in the world after potato. In India, based on an area and production, it was ranked second. The tomato crop suffers from >50 diseases of varied etiology like fungi, bacteria, phytoplasma, and viruses in different parts of the world. Among these pathogens, Ralstonia solanacearum species complex (RSSC) is a well-known soil-borne phytopathogenic bacterium causing lethal wilting disease in over 450 plant species and 54 botanical families (Sharma et al, 2005). The losses caused by bacterial wilt in tomato crops are varied from 2-95 per cent (Elphinstone et al., 2005; Wang et al, 2005; Singh et al., 2010; Muthoni et al., 2012) in the world depending on the cultivars, climatic conditions as well as virulence of the pathogen. The pathogen is considered to have the potential to be developed as a bioterrorist weapon. Strains of $R$. solanacearum species complex has been grouped as 5 races, 6 biovars, 4 phylotypes and 20 sequevars (Garcia et al, 2019).

In tomato, it is a very hard to manage bacterial wilt disease because of its soil-borne nature, longer survivability of the pathogen in absence of the natural host and variability. Recently, some alternative management strategies have been recommended for bacterial wilt such as microbes (Singh et al, 2016; Le et al, 2020) and induced resistance in plants (Hassan et al., 2013; Kurabachew et al., 2014). Plants have evolved two mechanisms to fend off infection caused by pathogen i.e. innate resistance and acquired or induced resistance (Kim et al., 2001), In the second category, need pre-treatment by chemicals or by bio-inducers which causes a plant to exhibit increased resistance to subsequent pathogen challenges. The plant disease-inducing agents have been used to stimulate the plant's defence mechanism by producing disease resistance substances without showing direct inhibitory effects on the pathogen (Dong et al, 2019). The plant activates many types of induced resistance during infection caused by different pathogens and chemical inducers like salicylic acid (SA) (Dong et al., 2019), benzothiadiazole, methyl jasmonate, $\beta$ aminobutyric acid (Cohen et al., 2016), DL-3aminobutyric acid, silicon. Kurabachew et al., (2013) reported that there are two types of inducing plant resistance and induced resistance viz., ISR (induced systemic resistance) and SAR (systemic acquired resistance).

Early and elevated levels of expressions of various defense enzymes are an important feature including peroxidase (POD), Superoxide dismutase (SOD) and catalase (CAT) during host pathogen interactions. Increases in POD activity are often associated with a progressive incorporation of phenolic compounds within the cell wall during incompatible plant-microbe/elicitor interactions (Adss et al., 2014). CAT is an antioxidative enzyme involved in oxidative burst generated transiently in plant-pathogen interactions. CAT is involved in regulation of $\mathrm{H}_{2} \mathrm{O}_{2}$ levels in plant tissues (Mandal et al., 2011). Real Time PCR (RT-PCR) has become an extensively applied technique in molecular plant pathology and it has been extensively used for quantification of different enzymes gene expression activities. The pre-treatment with BABA or other elicitors can be applied to the plant against future stress (FloryszakWieczorek et al., 2016; Meller et al., 2018). There are some findings which stated that the stress establishment is a comparatively uncommon case to reset at the time of stress recovery (Crisp et al., 2016; Hilker et al., 2016).

In the present study, we studied the induction of defense related enzymes by $\beta$-aminobutyric acid against Ralstonia solanacearum, the relative expression pattern of enzyme- 
responsive genes and wilt incidence in susceptible and resistant cultivars of tomato under Phytotron conditions.

\section{Materials and Methods}

\section{Bacterial culture and growth condition}

The $R$. solanacearum strain UTT-25 (race 1, biovar 3, phylotype I) was obtained from Division of Plant Pathology, ICAR, Indian Agricultural Research Institue, New Delhi. The strain was streaked onto Casamino acidspeptone-glucose agar (Hi -Media) medium (Schaad et al., 2001) and then grown at $28 \pm 1$ ${ }^{\circ} \mathrm{C}$ for $48 \mathrm{~h}$. The culture was preserved in $20 \%$ glycerol at $-80{ }^{\circ} \mathrm{C}$ for further experiments.

\section{Plant inoculations and tissue collection}

Seeds of susceptible Pusa Ruby and resistant Hawaii7996 cultivars of tomato were grown in seed starter trays (96 wells) filled with the mixture of peat moss, vermiculite, and sand (ratio 2:1:1) under controlled conditions at 28 $\pm 2{ }^{\circ} \mathrm{C}$, R. H. $60 \pm 5 \%$, light $80 \mu \mathrm{E} / \mathrm{m}^{2}$ and a circadian cycle of 16 hours light and 8 hours darkness at National Phytotron Facility, IARI, New Delhi. The water was given daily to the plants as per requirement,. Twenty five- days old tomato seedlings of both the cultivars were transplanted in six-inch autoclave pot having $1 \mathrm{~kg}$ of the soil mixture each. Four treatments viz. T1: Control; T2: $R$. solanacearum UTT-25; T3: BABA; T4; $\mathrm{BABA}+R$. solanacearum were planned. After 5 days of transplanting, they were drenched with $\beta$ - Aminobutyric acid $(50 \mu \mathrm{M})$ $[0.720 \mathrm{mg}$ in $100 \mathrm{ml}$ ethanol $(95 \%)]$ at the root zone of the plants. Then, $48 \mathrm{~h}$ old $R$. solanacearum culture $\left(10^{9} \mathrm{cfu} / \mathrm{mL}\right) @ 40 \mathrm{ml}$ was inoculated either alone or in combinations with the chemical. Uninoculated plants were drenched with sterilized distilled water and used as a control of both cultivars, with three replications. The experiment was repeated twice and pooled data were presented.

\section{Preparation of enzyme extracts}

About 0.5 g leaf tissue of tomato cvs. Pusa Ruby and Hawaii7996 were collected from each treatment for enzyme extraction at intervals of 6, 24, 48, and 96 hpi. Leaf tissue was homogenized in $0.1 \mathrm{M}$ sodium phosphate buffer $(20 \mathrm{ml}), \beta$ mercaptoethanol $(0.2 \mathrm{ml})$ and 1.0 gram of insoluble polyvinyl pyrrolidone (PVPP) and centrifuged at 12000 rpm for $30 \mathrm{~min}$ at $4^{0} \mathrm{C}$. The supernatant was measured and as per the ammonium sulphate concentration. After $1 \mathrm{~h}$ supernatant was centrifuged at $12000 \mathrm{rpm}$ for 30 minutes at $4^{\circ}$ $\mathrm{C}$ and pellets were resuspended in extraction buffer $(3 \mathrm{ml})$, for the assay of the scavenging enzyme viz. Super oxide dismutase (SOD), Catalase (CAT), Peroxidase (POD) and photosynthetic pigments.

\section{Estimation of peroxidase activity}

Peroxidase activity was estimated as method described by Kar and Mishra (1976). Potassium phosphate buffer $(2 \mathrm{ml}), 1 \mathrm{ml}$ of hydrogen peroxide $\left(\mathrm{H}_{2} \mathrm{O}_{2}\right)$ and $1 \mathrm{ml}$ of pyrogallol were mixed together. The $\mathrm{OD}_{420}$ value was measured for 5 minutes and one unit of enzyme was defined by the change in absorbance of 0.1 per minute. Calculation of specific activity was done by using the formula: $(\mathrm{A} \times 3 / 0.1) / 3=$ specific activity $/ \mathrm{min} / \mathrm{mg}$ protein. $\mathrm{A}=$ Difference of absorbance of sample and the control (OD S OD C).

\section{Estimation of superoxide dismutase activity}

Superoxide dismutase activity was determined using a NBT method as described by Beauchamp and Fridovich (1971). The 
SOD activity was measured by Optical density $\mathrm{OD}_{560}$. The $\mathrm{OD}$ value of reaction solution, the reduction of NBT by $50 \%$ was considered as 1 unit for enzyme activities. Calculation of specific activity of SOD was done by using the formula. (100-(OD S/OD LC) 100$) / 50=x$. Where, $x / m g$ protein in enzyme extract $=$ specific activity in units 1 unit is defined as the $50 \%$ reduction in the blue color formed by NBT/30 minutes/mg protein. $\mathrm{OD} \mathrm{S}=\mathrm{OD} \mathrm{T}-\mathrm{OD} \mathrm{C}, \mathrm{OD} \mathrm{T}=$ Absorbance of sample, OD $\mathrm{C}=$ Absorbance of dark control and OD LS =Absorbance of light control.

\section{Estimation of catalase activity}

Assay of Catalase was estimated as method described by Kar and Mishra (1976). To the enzyme extract $0.5 \mathrm{ml}$, hydrogen peroxide $\left(\mathrm{H}_{2} \mathrm{O}_{2}\right) 1 \mathrm{ml}$, distilled water $1 \mathrm{ml}$ and phosphate buffer $2 \mathrm{ml}$ were added against the control which have $4.5 \mathrm{ml}$ reaction mixture containing the enzyme extract $(500 \mu l)$, distilled water $2 \mathrm{ml}$, and $2 \mathrm{ml}$ of potassium phosphate (pH $500 \mathrm{mM})$ buffer were added one after and reaction was started by adding enzyme extract, and the sample was analyzed using UV-VIS Spectrophotometer, Hitachi (U-2900) at $240 \mathrm{~nm}$. Absorbance was recorded at every 60 seconds against corresponding control of each sample. Specific activity calculation was done by using the formula as $(\mathrm{A} \times 3) / 0.5)=$ specific activity/min/mg protein in enzyme extract. Where, $\mathrm{A}=$ specific activity

\section{RNA extraction and cDNA synthesis}

Samples of both cultivars (100 mg) were collected from tomato plant at mid-stem just above the cotyledon $(6,24,48$ and 96hpi) and immediately stored at $20^{\circ} \mathrm{C}$ temperatures to avoid degradation. RNA was extracted from the treated samples using the RNAse Plant Kit (Genetix Biotech Asia Pvt. Ltd.) including
DNase I treatment according to the manufacturer's instructions. The quality of DNAse-treated samples was tested by running the samples of purified RNA on agarose gel (ribosomal RNA bands are visible with a ratio of approximately 2:1 from bacterial and plant RNA samples). RNA quantity and quality was determined using micro-spectrophotometer (NanoDrop Technologies). cDNA preparation was also carried out with $1 \mu \mathrm{g}$ of total RNA using the Verso cDNA kit (Thermo Scientific, Epsom, UK) with random hexamer primers according to the manufacturer's instructions. cDNA synthesis was carried out to study the expression of enzymatic-responsive genes at various hours post-infection.

\section{Gene expression analysis by qRT-PCR}

The relative expression analysis of pathogenesis-related genes was conducted in resistant cv. Hawaii-7996 and susceptible cv. Pusa Ruby of tomato plant was analyzed at 6 , 24, 48 and 96hpi time intervals. Quantitative RT-PCR primers of pathogenesis-related genes POD, SOD, Catalase and one Gapdh (normalization gene) were designed using online Primer-3 software from the relevant Gene Bank (NCBI) mRNA sequences of tomato. Real time was performed in triplicate $20 \mu 1$ reactions using SYBR Green Mastermix (1X), $400 \mathrm{nM}$ forward and reverse primers, and $50 \mathrm{ng}$ template cDNA. These reactions were performed on an IQ5 Real-Time PCR System (BIO-RAD). Cycling parameters consist of initial denaturation at $95.0^{\circ} \mathrm{C}$ for 3 min followed by 40 cycles of $95^{\circ} \mathrm{C}$ for $10 \mathrm{sec}$ and $52^{\circ} \mathrm{C}$ for $30 \mathrm{sec}$. The PCR products were further analyzed to verify the specificity of the marker with an increase of $0.5^{\circ} \mathrm{C}$ for 0.05 sec. Relative gene expressions cDNA samples were than separately quantified using nanodrop spectrophotometer (Thermofisher). DNA contamination was also checked and no-template reactions served as controls in cDNA samples, lacking reverse transcriptase. 
The outcome data was presented as fold change in relative defence gene expression in infected tomato plants relative to control plants (treated with sterile distilled water). By analyzing the melting curve we can confirm the absence of non-specific products and primers-dimers.

\section{Data analysis}

Comparative analysis was done by using Biorad IQ5 software:

$$
\begin{aligned}
& \text { Fold change in target gene expression (Expt/control) } \\
& \text { Fold change in reference gene expression (Expt./control) }
\end{aligned}
$$

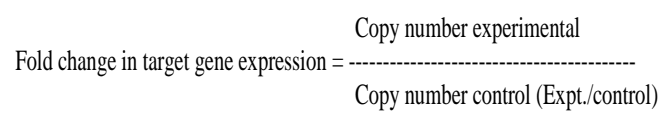

$$
\begin{aligned}
& \begin{aligned}
& \text { Fold change in reference gene expression= } \frac{\text { Copy number experimental }}{\text { Copy number control (Expt//control) }} \\
& \text { Co- }
\end{aligned}
\end{aligned}
$$

The equation shows a mathematical model of relative expression ratio in real-time PCR. The ratio of target gene is expressed in a sample versus a control in comparison of reference gene. The sample and control dataset of real-time PCR was analyzed with appropriate Bioinformatics and Statistical program for the estimation of relative expression of gene using real-time PCR and the result normalized to GAPDH housekeeping gene (reference gene). The data was statistically evaluated, interpreted and analyzed using Biorad IQ5 software.

\section{Disease parameters}

The observation of bacterial wilt-intensity, population of $R$. solanacearum from rhizosphere, plant growth parameters was done. At the time of harvesting, survived plants were sampled to get wilt intensity, fresh and dry weight. The wilt intensity was investigated at 7 days intervals up to 60 days. The calculation was done the average percentage wilt for each treatment. Disease rating was recorded by using following scale: $1=$ no symptoms; $2=$ one leaf wilted; $3=2-3$ leaves wilted; $4=4$ or more leaves wilted; 5: whole plant wilted (dead plant). Calculate the wilt incidence 30 days after inoculation, using the following formula (Schaad et al., 2001).

Wilt intensity $(\%)(\mathrm{I})=\left[\sum\left(\mathrm{n}_{\mathrm{i}} \mathrm{x} \mathrm{v}_{\mathrm{i}}\right) \div(\mathrm{V}\right.$ x N$\left.)\right]$ 100

Where, $\mathrm{n}_{\mathrm{i}}=$ number of plants with respective disease rating; $v_{i}=$ disease rating $(1,2,3,4$ or 5); $\mathrm{V}=$ the highest disease rating and $\mathrm{N}=$ the number of plants observed. Growth promotion efficacy was calculated on dry weight of plant as described by Singh et al., (2016).

\section{Statistical analysis}

Three independent biological replications of each sample (Control, Ralstonia solanacearum, BABA, BABA + Ralstonia solanacearum) were used for all described experiments. Results were represented as mean \pm standard deviation (SD) values and each experiment was repeated at least twice with similar results. All statistical analysis were performed in Opstat software which was available online on HAU university website (hau.ac.in) and all experiments were carried out under Randomized Block Design (RBD) with and without transformation. One-factor analysis of variance (ANOVA) was done to identify the significant difference between the treatments and the means were separated by using multiple comparison test as done to calculate i.e. Duncan`s multiple range tests (DMRT) values at a 0.05 probability.

\section{Results and Discussion}

In tomato, bacterial wilt disease caused by $R$. solanacearum was a very serious problem across the world including India, where it 
affects the crops significantly by reducing the production and productivity (Singh et al, 2016; Hamamouch et al., 2011). Tomato seedlings of both resistant (Hawaii 7996 and susceptible (Pusa Ruby) cultivars of tomato produced significantly high amount of POD, CAT and SOD after the treatment with bacterial pathogen $R$. solanacearum. The role of defense-related enzymes in imparting resistance in tomato with chemical elicitor against $R$. solanacearum was investigated by quantifying enzymes activity and gene expression of three defense-related enzymes peroxidase, catalase and superoxide dismutase. Generally, it was believed that beneficial bacteria make the plant more tolerant to the pathogen by stimulating induced systemic resistance (ISR) (Van et al, 2009). Allen et al., (2005) proved in his study that $\mathrm{H}_{2} \mathrm{O}_{2}$ appears to be a key element involved in disease resistance to pathogen. Moreover, Heil et al., (2002) reported that the interaction between plants and pathogens may lead either to be a successful infection (compatible response) and resistance (incompatible response). In the present study, defense enzyme activities of POD and accumulation CAT and SOD was increased significantly in tomato resistant cultivar Hawaii 7996 plants treated with challenged with $R$. solanacearum as compared to susceptible cultivar Pusa Ruby. Induced systemic resistance (ISR) in tomato by enriching the activity of oxidant and antioxidant enzymes related to plant defense response at different stages.

According to our experiment, the POD enzyme activity was accessed spectrophotometrically in the tomato plant tissue after inoculated with chemical elicitor beta butyric acid (BABA) @ $50 \mu \mathrm{M} /$ lit in combination with $R$. solanacearum or only $R$. solanacearum and control (inoculated with water). The POD activity was recorded significantly maximum after treated with
$\mathrm{BABA}+R$. solanacearum in resistant $\mathrm{cv}$. (Hawaii7996) (5.36 min/mg protein) at 48hpi (Table 1) followed by treated with $R$. solanacearum (3.56 $\mathrm{min} / \mathrm{mg}$ protein). The POD enzyme activity was increased in all the treatment up to $48 \mathrm{hpi}$ after that it was recorded deceasing trend. Overall, the resistant cv. Hawaii7996 showed significantly higher level of POD enzyme activity after inoculation as compared to susceptible cv. Pusa Ruby. Our findings are similar with the results of the earlier studies of Eman et al (2016) on potato against $R$. solanacearum. $\mathrm{Wu}$ et al (2016), states that in pepper plant, the highest POD activity indicated the extra sensitive to infection by Phytophthora capsici as POD-mediated enzymatic reactions are enhanced in infected plants. Enhancement of POD activity in plant is an essential factor in increasing resistance to the plant disease. In the present study, we observed the quick response of POD when tomato treated with $R$. solanacearum, indicates a possible role of the enzyme during pathogen infection and hostresistance. The fact that POD activity was higher in resistant than in susceptible cultivars indicates that POD might have played a specific role in triggering the development of host resistance.

Superoxide Dimutase (SOD) enzyme activity was observed maximum in resistant cv. (Hawaii7996) (3.65 $\mathrm{min} / \mathrm{mg}$ protein) followed by and after treatment with BABA $+R$. solanacearum at 48hpi which was slightly higher than the susceptible cv. of tomato (2.73 $\mathrm{min} / \mathrm{mg}$ protein). The activity of SOD enzyme was increased from 6hpi to 48 hpi in all the treatments and then after it was declined at 96hpi. Overall, study indicates that significant maximum level of SOD enzyme activity was determined in resistant cv. Hawaii7996 as compared to susceptible cv. Pusa Ruby.

Catalase (CAT) enzyme activity in resistant cv. (Hawaii7996) (31.58 $\mathrm{min} / \mathrm{mg}$ protein) was 
observed significantly higher after treatment with $\mathrm{BABA}+R$. solanacearum at $48 \mathrm{hpi}$ which was higher than the Pusa Ruby (25.58 $\mathrm{min} / \mathrm{mg}$ protein) However, the significant increase level of CAT activity was noticed in combination of BABA $(50 \mu \mathrm{m})+R$. solanacearum in both and Hawaii7996 and susceptible cv. Pusa Ruby (Table 1). These results were in harmony with findings of Navodit and Prabir 2014. Another study reported that the restriction of $R$. solanacearum growth could be due to the antimicrobial activity of $\mathrm{H}_{2} \mathrm{O}_{2}$, which is strongly increased around bacterial cells. Consequently, the high CAT susceptible cultivars restrict $\mathrm{H}_{2} \mathrm{O}_{2}$ action against $R$. solanacaerum. Overall, a significantly high level of CAT enzyme activity was observed in resistant $\mathrm{cv}$. than susceptible $\mathrm{cv}$. as compared to control.

Table.1 Effect of $\beta$ - Aminobutyric acid on defence related enzymes activities in resistant and susceptible cvs. of tomato against $R$. solanacearum under glasshouse conditions

\begin{tabular}{|c|c|c|c|c|c|c|c|c|c|}
\hline \multirow{2}{*}{$\begin{array}{c}\text { Enzyme } \\
\text { specific activity } \\
\text { (min/mg } \\
\text { protein) }\end{array}$} & \multirow[t]{2}{*}{ Treatment } & \multicolumn{4}{|c|}{ Pusa Ruby } & \multicolumn{4}{|c|}{ Hawaii7996 } \\
\hline & & 6hpi & 24hpi & 48hpi & 96hpi & 6hpi & 24hpi & 48hpi & 96hpi \\
\hline \multirow[t]{5}{*}{ POD } & R. solanacearum & $2.26^{\mathrm{ab}}$ & $2.67^{b}$ & $2.93^{\mathrm{b}}$ & $1.36^{\mathrm{b}}$ & $2.72^{\mathrm{ab}}$ & $2.83^{\mathrm{b}}$ & $3.56^{\mathrm{b}}$ & $2.01^{\mathrm{c}}$ \\
\hline & $\begin{array}{l}\mathrm{BABA}+R . \\
\text { solanacearum }\end{array}$ & $2.72^{a}$ & $3.54^{\mathrm{a}}$ & $3.76^{\mathrm{a}}$ & $2.21^{\mathrm{b}}$ & $3.97^{c}$ & $4.27^{\mathrm{a}}$ & $5.36^{\mathrm{a}}$ & $3.26^{\mathrm{a}}$ \\
\hline & Control (water) & $1.17^{\mathrm{c}}$ & $1.19^{\mathrm{b}}$ & $2.09^{\mathrm{b}}$ & $2.37^{\mathrm{a}}$ & $1.27^{\mathrm{c}}$ & $2.22^{\mathrm{b}}$ & $1.99^{\mathrm{c}}$ & $2.99^{\mathrm{b}}$ \\
\hline & $\mathrm{CD}$ at $5 \%$ & 0.027 & 0.01 & 0.006 & 0.005 & 0.005 & 0.008 & 0.006 & 0.008 \\
\hline & CV \% & 7.08 & 2.33 & 1.24 & 1.14 & 1.13 & 1.8 & 1.94 & 1.13 \\
\hline \multirow[t]{6}{*}{ SOD } & Control (light) & $0.43^{\mathrm{b}}$ & $0.51^{\mathrm{b}}$ & $0.43^{\mathrm{d}}$ & $0.41^{\mathrm{c}}$ & $1.435^{\mathrm{c}}$ & $1.51^{\mathrm{b}}$ & $1.425^{\mathrm{b}}$ & $1.46^{\mathrm{c}}$ \\
\hline & Control (dark) & $0.79^{\mathrm{ab}}$ & $0.95^{\mathrm{a}}$ & $0.73^{\mathrm{a}}$ & $0.88^{\mathrm{a}}$ & $1.795^{\mathrm{bc}}$ & $1.91^{\mathrm{b}}$ & $2.25^{\mathrm{a}}$ & $1.97^{\mathrm{bc}}$ \\
\hline & R. solanacearum & $0.92^{\mathrm{a}}$ & $0.95^{b}$ & $1.08^{\mathrm{c}}$ & $0.71^{\mathrm{b}}$ & $1.19^{\mathrm{a}}$ & $2.47^{\mathrm{b}}$ & $2.80^{\mathrm{bc}}$ & $1.27^{\mathrm{b}}$ \\
\hline & $\begin{array}{l}\mathrm{BABA}+R . \\
\text { solanacearum }\end{array}$ & $0.80^{\mathrm{ab}}$ & $1.68^{b}$ & $2.73^{\mathrm{a}}$ & $1.84^{\mathrm{a}}$ & $2.32^{\mathrm{a}}$ & $2.79^{\mathrm{a}}$ & $3.65^{\mathrm{ab}}$ & $1.60^{\mathrm{b}}$ \\
\hline & $\mathrm{CD}$ at $5 \%$ & 0.13 & 0.08 & 0.08 & 0.11 & 0.02 & 0.41 & 0.07 & 0.04 \\
\hline & CV (\%) & 10.12 & 19.01 & 7.43 & 8.93 & 6.08 & 9.64 & 3.34 & 2.25 \\
\hline \multirow[t]{5}{*}{ Catalase } & R. solanacearum & $15.61^{\mathrm{a}}$ & $17.44^{\mathrm{a}}$ & $20.42^{\mathrm{ab}}$ & $13.49^{\mathrm{ab}}$ & $20.95^{\mathrm{b}}$ & $24.76^{\mathrm{a}}$ & $25.16^{\mathrm{b}}$ & $22.49^{b}$ \\
\hline & $\begin{array}{l}\mathrm{BABA}+R . \\
\text { solanacearum }\end{array}$ & 18.58 & $20.67^{b}$ & $25.58^{\mathrm{b}}$ & $17.91^{\mathrm{ab}}$ & $18.42^{\mathrm{a}}$ & $30.67^{b}$ & $31.58^{\mathrm{c}}$ & $29.91^{b}$ \\
\hline & Control (water) & $12.16^{\mathrm{b}}$ & $11.46^{\mathrm{b}}$ & $11.90^{\mathrm{ab}}$ & $13.53^{\mathrm{a}}$ & $20.74^{\mathrm{a}}$ & $22.75^{\mathrm{a}}$ & $20.90^{\mathrm{a}}$ & $19.53^{\mathrm{a}}$ \\
\hline & $\mathrm{CD}$ at $5 \%$ & 0.31 & 0.41 & 0.32 & 0.32 & 0.34 & 0.59 & 0.38 & 0.63 \\
\hline & CV \% & 6.40 & 8.81 & 8.53 & 8.26 & 5.25 & 8.87 & 6.62 & 10.94 \\
\hline
\end{tabular}

Mean \pm SE (Standard error) followed by the same letter do not differ significant according to Duncan's multiple range test at $\mathrm{p}=0.05$. Scheffe post hoc test. Means sharing different alphabetical (a, b, c, d, e, f, g, h) superscripts in a column significantly different $(\mathrm{p} \leq 0.05)$ 
Table.2 Plant growth promotion of tomato plant by Ralstonia solanacearum UTT-25

\begin{tabular}{|c|c|c|c|c|c|c|c|c|}
\hline \multirow[t]{2}{*}{ Treatments } & \multicolumn{4}{|l|}{ Pusa Ruby } & \multicolumn{4}{|l|}{ Hawaii7996 } \\
\hline & $\begin{array}{l}\text { Length of } \\
\text { tomato } \\
\text { plant }(\mathrm{cm})\end{array}$ & $\begin{array}{l}\text { Fresh } \\
\text { weight } \\
\text { (g/plant) }\end{array}$ & $\begin{array}{l}\text { Dry } \\
\text { weight } \\
\text { (g/plant) }\end{array}$ & $\begin{array}{l}\text { GPE \% } \\
\text { (based on } \\
\text { dry } \\
\text { weight) }\end{array}$ & $\begin{array}{l}\text { Length of } \\
\text { tomato } \\
\text { plant }(\mathrm{cm})\end{array}$ & $\begin{array}{l}\text { Fresh } \\
\text { weight } \\
\text { (gm) }\end{array}$ & $\begin{array}{l}\text { Dry } \\
\text { weight } \\
\text { (gm) }\end{array}$ & $\begin{array}{l}\text { GPE }(\%) \\
\text { based on dry } \\
\text { weight } \\
\text { tomato plant }\end{array}$ \\
\hline $\begin{array}{l}\text { R. solanacearum } \\
\text { UTT-25 }\end{array}$ & $34.5^{\mathrm{b}}$ & $10.5^{d}$ & $3.1^{\mathrm{d}}$ & 22.50 & $36.1^{b c}$ & $11.7^{c}$ & $2.9^{c}$ & -24.64 \\
\hline BABA $(50 \mu M)$ & $42.5^{\mathrm{a}}$ & $17.9^{b}$ & $4.4^{\mathrm{a}}$ & 10.00 & $40.5^{a}$ & $15.5^{b}$ & $4.6^{\mathrm{a}}$ & 17.95 \\
\hline 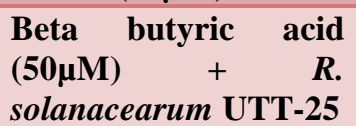 & $31^{b}$ & $12.2^{\mathrm{c}}$ & $4.1^{\mathrm{b}}$ & 2.50 & $31.5^{c}$ & $11.8^{c}$ & $4.2^{\mathrm{ab}}$ & 7.69 \\
\hline Control & $45^{\mathrm{a}}$ & $14.2^{\mathrm{a}}$ & $4.0^{\mathrm{c}}$ & 0 & $38.3^{a b}$ & $13.6^{\mathrm{a}}$ & $3.9 .0^{b}$ & - \\
\hline CD at $5 \%$ & 3.77 & 0.38 & 0.22 & - & 0.83 & 0.37 & 0.33 & - \\
\hline CV (\%) & 4.83 & 1.19 & 2.43 & - & 1.22 & 1.16 & 4.19 & - \\
\hline
\end{tabular}

Mean \pm SE (Standard error) followed by the same letter do not differ significant according to Duncan's multiple range test at $\mathrm{p}=0.05$. Scheffe post hoc test. Means haring different alphabetical (a, b, c, d, e) superscripts in a column significantly different $(\mathrm{p} \leq 0.05)$

Fig.1 Expression of peroxidase gene in tomato cvs. Pusa Ruby (Susceptible) and Hawaii7996 (Resistant) of treated with T1: untreated, T2: $R$. solanacearum, T3: BABA and T4: BABA $+R$. solanacearum at different intervals using RT- PCR

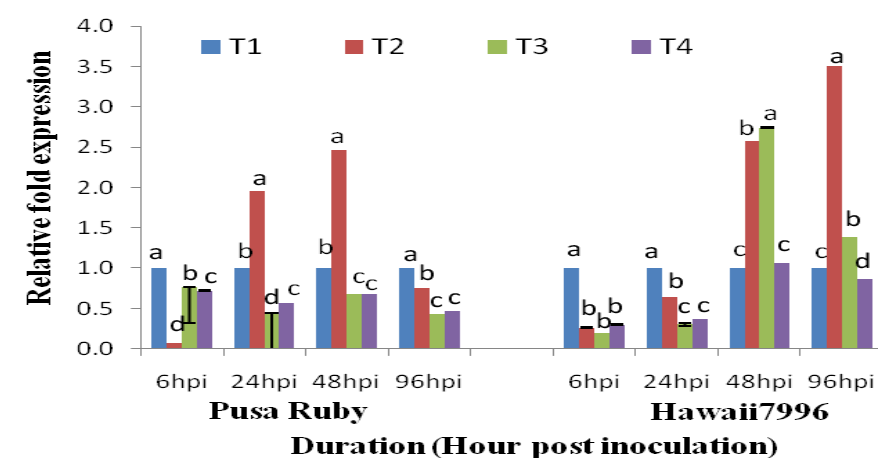

Fig.2 Expression of Catalase gene in tomato cvs. Pusa Ruby (Susceptible) and Hawaii 7996 (Resistant) treated with T1: untreated, T2: $R$. solanacearum, T3: BABA and T4: BABA $+R$. solanacearum at different intervals using RT- PCR.

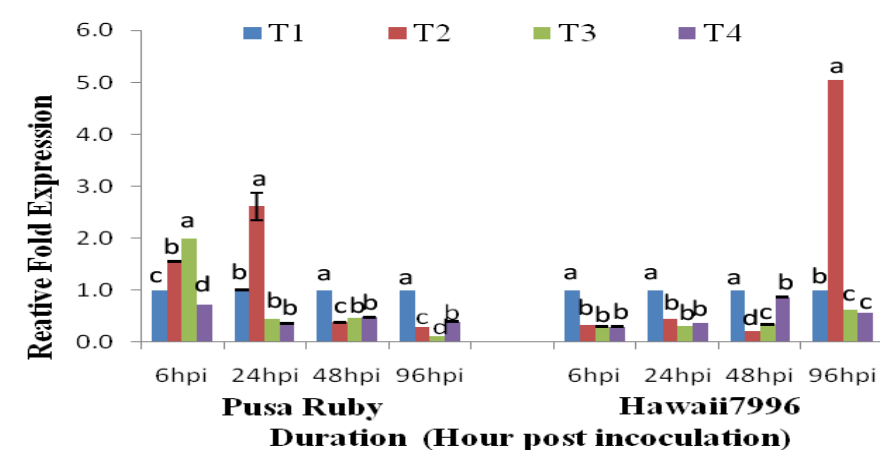


Fig.3 Expression of Superoxide dismutase gene in tomato cvs. Pusa Ruby (Susceptible) and Hawaii7996 (Resistant) treated with T1: Untreated, T2: $R$. solanacearum, T3: BABA and T4:

$\mathrm{BABA}+R$. solanacearum at different intervals using RT- PCR.

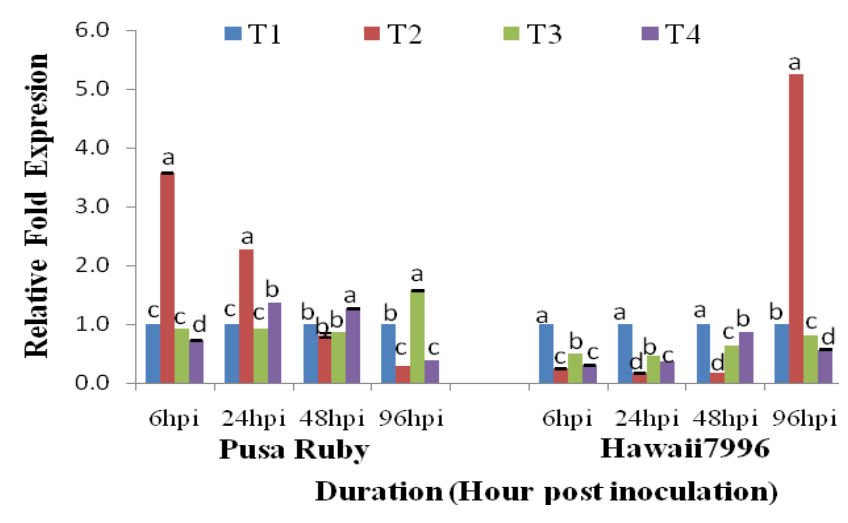

Fig.4 Development of wilt disease incidence in resistant cv. Hawaii 7996) and susceptible cv. Pusa Ruby cultivars of tomato under control conditions at different time period of infection

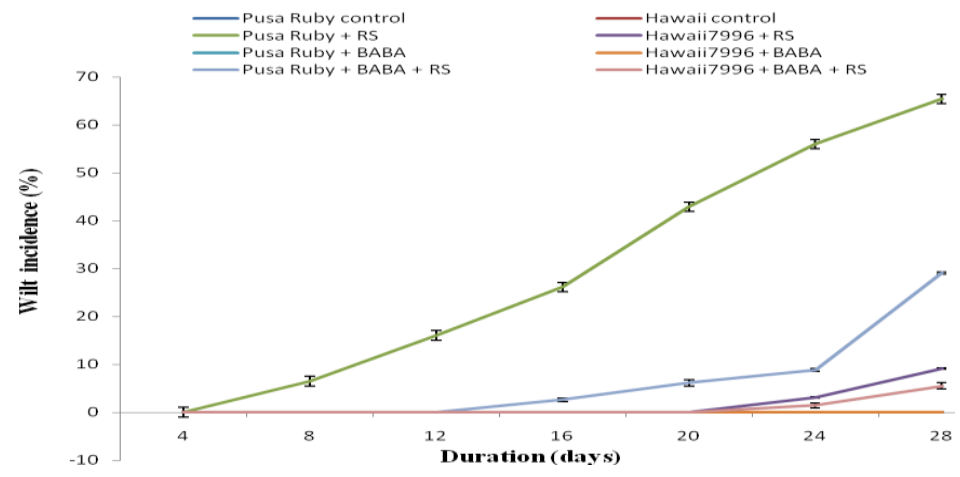

Expression of defense related genes in tomato induced by chemical inducers

In resistant (cv. Hawaii7996) and susceptible (cv. Pusa Ruby) cultivars of tomato, relative expression levels of three genes i.e. POD, Catalase and SOD genes were analyzed at intervals of 6, 24, 48 and 96hpi after giving four treatments i.e. T1: Control; T2: $R$. solanacearum (UTT-25); T3: BABA and T4; $\mathrm{BABA}+R$. solanacearum. Peroxidase (POD) gene, Pusa Ruby cv. treated with $R$. solanacearum (T2) showed significant $(\mathrm{P}<0.005)$ high level of relative expression 1.95 and 2.45 fold up-regulation at 24hpi and 48hpi respectively as compared to control. However, in resistant cv. Hawaii 7996, the maximum level of relative expression was observed 2.57, 2.74 and 1.06 fold upregulated in $\mathrm{T} 2, \mathrm{~T} 3$, and $\mathrm{T} 4$ treatments with POD gene at 48hpi as compared to control respectively. The changes in the relative expression of POD gene were significantly $(\mathrm{P}<0.005)$ increased after treated with pathogen $R$. solanacearum at 96hpi and showed 3.50 fold high level of expression in resistant cultivar treated with T2. However, Peroxidase gene was down-regulated and showed non-significant $(\mathrm{P}<0.005)$ expression at 6 and 24hpi with all the treatments in a resistant cultivar of tomato (Fig.1). RosasDíaz T et al., 2016 used a combination of exogenous hormone treatments, microarray analysis, and pathogen infections to analyze 
the suppression of the JA response exerted by protein $\mathrm{C} 2$. However, the results indicated that the $\mathrm{C} 2$ specifically affects certain JAinduced responses, namely defence and secondary metabolism, and showed that the plants expressing $\mathrm{C} 2$ are more susceptible to pathogen attack.

The relative expression of Catalase (CAT) gene was noted significant $(\mathrm{P}<0.005)$ high 1.55 and 2.61 fold up-regulation in susceptible cv. Pusa Ruby after treated with pathogen $R$. solanacearum (T2 treatment) as compared to control at 6 and $24 \mathrm{hpi}$ as compared to control, but non- significant variation in expression of Catalase was recorded in Hawaii7996 resistant cultivar. Catalase gene showed a non-significant $(\mathrm{P}<0.005)$ expression in susceptible cv. Pusa Ruby at 48 and 96hpi. In resistant cultivar, the non-significant $(\mathrm{P}<0.005)$ expression was observed in all the treatments, except $\mathrm{T} 2$, infected plants with only $R$. solanacearum showed a maximum of 5.04 fold up-regulated at 96h.p.i (Fig. 2).

In Pusa Ruby cultivar, the SOD gene showed a significant $(\mathrm{P}<0.005)$ maximum level of relative expression 3.57 fold up-regulation after treated with only pathogen $R$. solanacaerum (T2) after 6hpi as compared to control. However, at $24 \mathrm{hpi}$, the relative expression of SOD was monitored significantly $(\mathrm{P}<0.005)$ high 2.27 and 1.36 fold up-regulation with the $\mathrm{T} 2$ and $\mathrm{T} 4$ treatments in Pusa Ruby as compared to control, whereas resistant cv. Hawaii7996 showed a non-significant down-regulated. Moreover, the relative expression level of SOD gene in resistant cv. Hawaii7996 was noticed non-significant $(\mathrm{P}<0.005)$ downregulated in all treatments except $\mathrm{T} 2$ infected with the pathogen only that showed significantly $(\mathrm{P}<0.005)$ high level 5.24 fold up-regulation at 96hpi (Fig. 3).

\section{Wilt disease incidence/growth parameters}

Pusa Ruby and Hawaii7996 cultivars were treated with Beta butyric acid (BABA) $(50 \mu \mathrm{m})$ along with subsequent inoculation with and without $R$. solanacearum under controlled conditions under glasshouse conditions. Minimum wilt incidence $(5.54 \%)$ was recorded in BABA $(50 \mu \mathrm{m})$ in Hawaii7996 followed by Hawaii7996 without BABA treatment $(9.14 \%)$ and Pusa Ruby cultivar treated with BABA (29.10\%) after 28 days of inoculation of the pathogen. However, the wilt disease incidence was observed maximum in susceptible cv. Pusa Ruby (65.4\%) than the Hawaii 7996 resistant cultivar $(9.14 \%)$ of tomato plants (Fig. 4). The browning of vascular tissue and wilt intensity per cent was noticeably decreased when the plants were treated with BABA. However, the wilt incidence was increased in susceptible cv. Pusa Ruby than resistant cv. Hawaii7996 of tomato plant in due course of time. In our finding, it indicates that $R$. solanacearum able to penetrate and then after multiply in the susceptible (Pusa Ruby) plant tissue faster than the resistant cultivar (Hawaii7996). The population of bacteria reaches significantly $(\mathrm{P}<0.05)$ a certain level within 6 days to express wilt disease symptoms in susceptible cultivar Pusa Ruby, but in resistant cultivar, the appearance of the diseases was delayed about 10 days to express the disease symptoms. The complete wilting was started from 16 days of inoculation, accordingly we can say that wilt susceptibility was recorded from simultaneous rapid bacterial colonization and the bacterial population was increased in vascular tissues. From these findings, it's suggested that the anatomy of resistant cultivars (Hawaii7996) has a very important role in restricting the multiplication and spread of the pathogen in tomato. These outcomes indicate that chemical elicitors and resistant cultivars play a synergistic role to reduce bacterial wilt 
disease in tomato. Similar kinds of reduced disease progress with the application of BABA has been observed in case of bacterial head of broccoli (Pajot and Silue, 2005), halo blight of common bean (Martinez-Aguilar et al., 2016), bacterial speck of tomato (Baysal et al., 2007) and black rot of cabbage (Raghavendra et al., 2017). Our findings were also corroborative to the result of Chen et al., (2003) who coined that the host-resistance is the vital strategy for managing the bacterial wilt disease in tomato plant and specifically triggers the mechanisms which are responsible for wilt resistance in tomato are unknown. Although, various methods have used to manage the disease none of them is found effective to fully control the disease under field conditions.

It may be concluded that a decrease level of multiplication of bacterial pathogen in BABA + RS treated plants was attended by defense constituents' accumulation in plant tissue. Data in Table 2 showed that a significant variation was recorded among the treatments in both the tomato cultivars for the assessed total plant fresh weight, total plant dry weight and plant length. However, after the inoculation with BABA treated plants in both the cultivars showed a significant variations in plant growth of tomato and found growth promotion efficacy (GPE) 10.00 and $17.96 \%$ in Pusa Ruby and Hawaii7996 was recorded significantly the highest followed by BABA + $R$. solanacearum treated plants 2.50 and 7.69 $\%$ Pusa Ruby and Hawaii7996 respectively (Table 2). R. solanacearum treated plants significantly reduced the growth of tomato plants of both the cultivars significantly. The study indicates that BABA was found effective to the disease incidence as well as provided good health of the crops better growth and total biomass of both the cultivars of the tomato. These findings were somehow harmony with the Eman El-Argawy et al., (2016).
The our findings indicate that the resistant cv. Hawaii7996 showed resistance to bacterial wilt disease and also recommended for cultivation in wilt-prone areas. Chemical elicitor BABA @50 $\mu \mathrm{M}$ was effective to control bacterial wilt disease in tomato plants. Finally, peroxidase (POD), superoxide dismutase (SOD), and catalase (CAT) enzymes activities can be used as biochemical markers to reveal the resistance or susceptibility nature of tomato cultivars against bacterial wilt disease of tomato caused by $R$. solanacaerum. BABA makes an efficient alternative for the traditional chemical method of managing the disease. So the use of BABA against $R$. solanacearum in tomato might result in a novel environmentally friendly method for disease protection in the crops, which also will improve quality and productivity of the crop.

\section{Acknowledgement}

Authors are thankful to the Head, Division of Plant Pathology, ICAR- Indian Agricultural Research Institute, New Delhi and Director, Amity University, Manesar, Haryana for their support and encouragement during experimentations.

\section{References}

Adss IA. 2014. Different Gene Expression of Polygalacturonase (pehC) and Its Relationship to the Pathogenicity of Different $R$. solanacearum Isolates. Journal of Agriculture \& Environmental Sciences Damanhur University, Egypt 31: 48-62.

Allen C, Prior P, Hayward AC. 2005. Bacterial Wilt Disease and the Ralstonia solanacearum Species Complex. American Phyto pathological Society, St. Paul, MN, pp: 528.

Baysal 0, Gursoy Y2, Omek H, Cetinel B, Da Silva JAT.2007. Enhanced systemic resistance to bacterial speck disease 
caused by Pseudomonas syringae pv. tomato by DL-P-aminobutyric acid under salt stress. Physiol Plantarum 129: 493506.

Chen YY, Lin YM, Chao TC, Wang JF, Liu AC. 2009. Virus-induced gene silencing reveals the involvement of ethylene-, salicylic acid- and mitogen activated protein kinase-related defense pathways in the resistance of tomato to bacterial wilt. Physiol Plantarum 136 324-335.

Cohen Y, Vaknin M, Mauch MB. 2016. BABAinduced resistance: milestones along a 55year journey. Phytoparasitica 44: 513538.

Crisp PA, Ganguly D, Eichten SR, Borevitz JO, Pogson BJ. 2016. Reconsidering plant memory: intersections between stress recovery, RNA turnover, and epigenetics. Sci. Adv 2:e1501340 DOI1126/sciadv.1501340.

Elphinstone JG. 2005). The current bacterial wilt situation: a global overview. In Bacterial Wilt Disease and the Ralstonia solanacearum Species Complex ed. Allen, C., Prior, P., Hayward, A.C., 9-28. Minnesota: American Phytopathological Society Press.

Eman Argawy El, Ibrahim Adss A. 2016. Quantitative Gene Expression of Peroxidase, Polyphenoloxidase and Catalase as Molecular Markers for Resistance against Ralstonia solanacearum. American Journal of Molecular Biology 6: 88-100.

Floryszak WJ, Arasimowicz JM, Izbiańska K. 2016.The combined nitrate reductase and nitrite-dependent route of NO synthesis in potato immunity to Phytophthora infestans. Plant Physiol. Biochem 108: 468-477.

Garcia RO, Kerns JP, Theiessen L. 2019. Ralstonia solanacearum Species Complex: A Quick Diagnostic Guide, Plant Health Progress 20: 7-13.

Hamamouch N, Li C, Seo PJ, Park C, Davis EL. 2011. Expression of Arabidopsis pathogenesis-related genes during nematode infection. Mol. Plant Pathol 12: 355- 364.

Hassan MAE, Abo-Elyousr KAM. 2013. Activation of tomato plant defense responses against bacterial wilt caused by Ralstonia solanacearum using DL-3aminobutyric acid (BABA). Eur J Plant Pathol 136: 145-157.

Hayward AC. 1991. Biology and epidemiology of bacterial wilt caused by Pseudomonas solanacearum. Annu Rev Phytopathol 29: 65-87.

Heil M, Bostock RM. 2002. Induced systemic resistance (ISR) against pathogens in the context of induced plant defences. Ann. Bot 89: 503-512.

Hilker M, Schwachtje J, Baier M, Balazadeh S, Bäurle I, Geiselhardt S. 2016. Priming and memory of stress responses in organisms lacking a nervous system: priming and memory of stress responses. Biol. Rev 91: 1118-1133.

Kim SK, Lund J, Kiraly M. 2001. A gene expression map of Caenorhabditise legans. Science signaling 293 no.5537, p, 2087.

Kong HG, Bae JY, Lee HJ, Joo HJ, Jung EJ, Chung E. 2014. Induction of the viable but non-culturable state of Ralstonia solanacearum by low temperature in the soil microcosm and its resuscitation by catalase. PLoS One 9e109792, doi 10.1371/journal.pone.0109792.

Kurabachew H, Wydra K. 2013. Characterization of plant growth promoting rhizobacteria and their potential as bio-protectant against tomato bacterial wilt caused by Ralstonia solancearum. Biol. Control 67: 75-83.

Kurabachew H, Wydra K. 2014. Induction of systemic resistance and defense related enzymes after elicitation of resistance by rhizobacteria and silicon application against Ralstonia solanacearum in tomato (Solanum lycopersicum). Crop Protection 57: 1-7.

Li H, Dong Z, Ma C, Tian X, Xiang Z, Xia Q. 2019. Discovery of powdery mildew resistance gene candidates from Aegilops 
biuncialis chromosome $2 \mathrm{Mb}$ based on transcriptome sequencing. PLoS ONE 14(11) e0220089.

Mandal S, Das RK, Mishra S. 2011. Differential Occurrence of Oxidative Burst and Antioxidative Mechanism in Compatible and Incompatible Interactions of Tomato and Ralstonia solanacearum. Plant Physiology and Biochemistry 49: 117123.

Martinez-Aguilar K, Ramirez-Carrasco G, Hernandez-Chavez JL, Barraza A, Alvarez-Venegas R. 2016. Use of BABA and INA as activators of a primed state in the common bean (Phaseolus vulgaris L.). Front Plant Sci 7. doi: 10.3389/ fpls.2016.00653.

Meller B, Kuźnicki D, Arasimowicz-Jelonek M, Deckert J, Floryszak-Wieczorek J. 2018. BABA-primed histone modifications in potato for intergenerational resistance to Phytophthora infestans. Front. Plant Sci. 91228 10.3389/fpls.2018.01228.

Muthoni J, Shimelis H, Melis R. 2012. Management of bacterial wilt [Ralstonia solanacearum Yabuuchi et al., 1995 of potatoes: opportunity for host resistance in Kenya. J. Agric. Sci 4: 64-78.

Navodit G, Prabir KP. 2014. Induction of Systemic Resistance in Tomato by Fruit Extracts of Azadirachta indica. Reviews of Liter 2: 1-27.

Pajot E, Silue D. 2005. Evidence that DL-3aminobutyric acid and acibenzolar-Smethyl induce resistance against bacterial head rot disease of broccoli. Pest manag Sci 61: 1110-1114.

Raghavendra BT, Singh D, Yadav DK. 2017. $\beta$ amino butyric acid as novel defense activator against Xanthpmonas campestris pv. campestris causing black rot of cabbage. Environment \& Ecology 35 (2A): $945-948$.

Sharma JP, Kumar S. 2005. Occurrence of biovar of race 1 of Ralstonia solanacearum in Jharkhand. Indian Phytopath 58: 362.

Singh D, Sinha S, Yadav DK, Sharma JP, Srivastava DK.(2010. Characterization of biovars/races of Ralstonia solanacearum incitant of bacteria wilts in solanaceous crops. Indian Phytopath 63: 262-265.

Singh D, Yadav D.K, Chaudhary G, Rana VS, Sharma RK. 2016. Potential of Bacillus amyloliquefaciens for biocontrol of bacterial wilt of tomato incited by Ralstonia solanacearum. J Plant Pathol Microbiol 7:1.

Van der ES, Van Wees SCM, Pieterse CMJ, 2009. Jasmonate signaling in plant interactions with resistance-inducing beneficial microbes. Phytochemistry 70: 1581-1588.

Wang, J.F., Lin, C.H. 2005. Integrated Management of Tomato Bacterial Wilt, Taiwan: AVRDC-The World Vegetable Center. 1-16.

Wu L, Xian W, Ma Y, Guo Q. 2016. Effects of Phytophthora capsici on activities of POD, SOD, MDA in leaves of grafted pepper. J. Qinghai Univ 34: 2-5.

Le Khanh Duy, Kim Jueun, Yu Nan Hee, Kim Bora, Lee Chul Won, Kim Jin-Cheol. 2020. Biological Control of Tomato Bacterial Wilt, Kimchi Cabbage Soft Rot, and Red Pepper Bacterial Leaf Spot Using Paenibacillus elgii JCK-5075. Front Plant Sci. 11: 775. 3389/fpls.2020.00775

\section{How to cite this article:}

Garima Chaudhary, Dinesh Singh and Manju Sharma. 2021. Induction of Defense Related Enzymes by $\beta$-aminobutyric Acid against Ralstonia solanacearum in Resistant and Susceptible Cultivars of Tomato. Int.J.Curr.Microbiol.App.Sci. 10(02): 1285-1297. doi: https://doi.org/10.20546/ijcmas.2021.1002.152 